\title{
FEED ENRICHMENT WITH FISH OIL TO INCREASE EEL GROWTH RATE Anguilla bicolor (McCelland, 1844)
}

\author{
Mira Ismayanti*1, Tarsim, Limin Santoso, dan Dwi Mulyasih*2
}

\begin{abstract}
Eel (Anguilla bicolor) is a export commodity fish in fisheries sector and has has high economic value but has slow growth. One method to accelerate eel growth is through feeding with the enrichment of fish oil. The aim of this research is to know the increase of growth rate of eel fish fed with the enrichment of essential fatty acids with fish oil. The study used 3 treatments and 3 replications ie A $10 \%$ fish oil / control), B (1.5\% fish oil), and C (3\% fish oil). Parameters observed included specific growth rate, feed consumption total, feed efiesiensi, fat retention, survival rate. The supporting parameters are water quality. The result of research obtained were tabulated and analyzed by excel 2013 program and SPSS v. 20.0. with 95\% confidence interva and continued by Duncan test. The results showed that there was a significant effect $(P<0.05)$ on the growth rate of eel fish fed with the enrichment of essential fatty acids with fish oil. Treatment $C$ (3\% fish oil) is the optimum dose because it has the best growth performance and best feed efficiency that is specific growth rate $(4,61 \% \pm 0,0075)$, total feed consumption $(246,3 \mathrm{~g} \pm$ $50,1)$, feed efiesiensi $(42,5 \% \pm 3,74)$, fat retention $(2,97 \% \pm 0,148)$ and survival rate $(86,7 \% \pm 11,5)$
\end{abstract}

Keywords: eel fish, fatty, fish oil, growth

\section{Pendahuluan}

Ikan sidat (Anguilla bicolor) merupakan jenis budidaya ikan yang mempunyai nilai ekonomis tinggi dan merupakan komoditas ekspor dari sektor perikanan (Purwanto, 2007). Menurut Hagesti et al. (2014) bahwa cina membutuhkan pasokan ikan sidat mencapai 70.000 ton per tahunnya, namun hanya $30 \%$ yang mampu terpenuhi. Selain itu Jepang dikenal sebagai negara pengimpor sidat terbesar di dunia, mereka memerlukan kurang lebih dari 300.000 ton ikan sidat per tahunnya (Affandi et al., 2013). Penurunan budidaya ekspor tersebut merupakan dampak dari kendala budidaya ikan sidat yaitu pertumbuhan ikan yang cukup lama. Sasongko et al. (2007) menyatakan bahwa ikan sidat (A. bicolor) memiliki pertumbuhan lambat. Salah satu upaya untuk meningkatkan produksi ikan sidat yang dibudidayakan adalah dengan

\footnotetext{
${ }^{1}$ E-mail: miraismayanti9@gmail.com

2 Jurusan Perikanan dan Kelautan, Fakultas Pertanian, Universitas Lampung

Jl. Prof. S. Brodjonegoro No.1 Gedong Meneng Bandar Lampung, 35145
} 
mempercepat pertumbuhannya melalui pemberian pakan.

Menurut Djajasewaka (1990), pakan yang dimakan oleh ikan mempunyai fungsi untuk memelihara kelangsungan hidup juga untuk pertumbuhan. Untuk mencapai pertumbuhan optimal dari ikan, maka pakan yang diberikan harus mempunyai kualitas yang tinggi. Salah satu cara untuk meningkatkan kualitas pakan yakni dengan menggunakan pakan buatan yang diperkaya dengan minyak ikan.

Menurut Leaver et al. (2008) lemak atau lipid berperan utama sebagai sumber asam lemak esensial bagi ikan. Lemak sangat berperan untuk pertumbuhan, perkembangan, dan reproduksi pada ikan. Pentingnya peranan asam lemak terhadap pertumbuhan ikan dan masih terbatasnya informasi tentang kebutuhan nutrisi ikan sidat, maka perlu dilakukan penelitian untuk mendapatkan kadar lemak yang tepat dalam pakan dengan cara menambahkan minyak ikan dalam rangka meningkatkan kinerja pertumbuhan.

\section{Metode}

Penelitian ini dilaksanakan pada bulan Desember 2017 sampai dengan Januari 2018. Rancangan yang digunakan dalam penelitian ialah Rancangan Acak Lengkap (RAL) dengan 3 perlakuan A tanpa pengkayaan $(0 \%)$, B pengkayaan minyak ikan $1,5 \%$, dan $\mathrm{C}$ pengkayaan minyak ikan 3\% dan tiga kali ulangan.

Laju Pertumbuhan Spesifik (LPS) Pertambahan panjang dan bobot tubuh ikan selama masa waktu pemeliharaan. (Fitriah, 2004).
Pengukuran laju pertumbuhan spesifik ini dilakukan setiap dua puluh hari sekali dan laju pertumbuhan harian ditunjukan dalam satuan persentase $(\%)$ dengan rumus sebagai berikut (Zonnevelt et al., 1991).

$$
L P S=\frac{\ln W t-\ln W o}{\mathrm{t}} \times 100 \%
$$

Keterangan:

$\mathrm{Wt}=$ bobot akhir sidat $(\mathrm{g})$

Wo $=$ bobot awal sidat $(\mathrm{g})$

$\mathrm{t}=$ waktu pemeliharaan

\section{Jumlah konsumsi pakan (JKP)}

Jumlah kebutuhan suatu populasi ikan terhadap sumber makanannya (Gerking dan Shelby, 1972). Jumlah konsumsi pakan dihitung dengan mengurangi jumlah awal pakan yang disediakan dengan jumlah pakan sisa yang terpakai untuk ikan.

JKP = Jumlah pakan yang diberikan Sisa pakan yang telah dikeringkan

\section{Efisiensi Pakan}

Pertambahan bobot ikan per jumlah pakan yang diberikan. Card dan Nesheim (1972) menyatakan bahwa nilai efisiensi pakan menunjukan banyaknya pertambahan bobot yang dihasilkan dari satu kilogram pakan yakni semakin tinggi nilai efisiensi, maka jumlah pakan yang diperlukan untuk menghasilkan satu kilogram daging akan semakin sedikit. Cara menghitung efisiensi pakan menurut Zonneveld (1991).

$$
\mathrm{EP}=\frac{(\mathrm{Wt}+\mathrm{Wm})-\mathrm{Wo})}{\mathrm{F}} \times 100 \%
$$

Keterangan:

$\mathrm{Wt}=$ bobot akhir pemeliharaan $(\mathrm{g})$ 


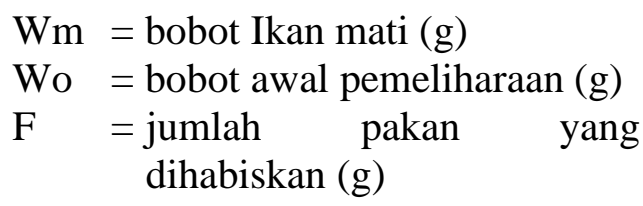

Retensi Lemak

Peningkatan persentase lemak pada ikan berdasarkan jumlah lemak yang diberikan. Adapun rumus retensi lemak adalah sebagai berikut (Takeuchi, 1988).

Keterangan:

$$
\mathrm{RL}=\frac{\mathrm{F}-\mathrm{I}}{\mathrm{L}} \times 100 \%
$$

$\mathrm{F}=$ jumlah lemak tubuh ikan pada akhir pemeliharaan $(\mathrm{g})$

I = jumlah lemak tubuh ikan pada awal pemeliharaan $(\mathrm{g})$

$\mathrm{L}=$ jumlah lemak yang dikonsumsi ikan $(\mathrm{g})$

\section{Tingkat Kelangsungan Hidup}

Persentasi jumlah ikan yang hidup diawal penelitian dengan jumlah ikan yang hidup diakhir penelitian. Rumus menghitung tingkat kelangsungan hidup menurut (Effendi, 1979).

Keterangan:

$$
\mathrm{TKH}=\frac{\mathrm{Nt}}{\mathrm{No}} \times 100 \%
$$

$\begin{aligned} \mathrm{Nt}= & \text { Jumlah ikan pada akhir } \\ & \text { pemeliharaan (ekor) } \\ \mathrm{No}= & \text { jumlah ikan pada awal } \\ & \text { pemeliharaan (ekor) }\end{aligned}$

\section{Uji Proksimat Pakan dan Tubuh Ikan}

Pelaksanaan uji proksimat tubuh ikan sidat menggunakan prosedur menurut Takeuchi (1988). Pengujian ini dilakukan untuk mengetahui kadar protein, lemak, karbohidrat, air, abu dan serat kasar yang terdapat pada pakan dan tubuh sidat.

\section{Kualitas Air}

Parameter kualitas air yang diukur selama penelitian meliputi Suhu, $\mathrm{pH}$ dan oksigen terlarut (DO) merupakan parameter utama yang mempengaruhi kondisi perairan. Pengukuran kualitas air ini dilakukan pada awal, tengah dan akhir masa pemeliharaan ikan sidat.

\section{Analisis data}

Analisis data dilakukan secara deskriptif dan kuantitatif. Data yang diperoleh dari setiap pengamatan parameter akan ditabulasi dan dianalisis menggunakan program excel 2013 dan SPSS v.20.0. dan diuji lanjut menggunakan uji Duncan.

\section{Hasil dan Pembahasan}

\section{Laju Pertumbuhan Spesifik}

Hasil analisis ragam menunjukan bahwa penambahan minyak ikan pada pakan buatan dengan dosis yang berbeda berpengaruh terhadap laju pertumbuhan spesifik ikan sidat $(A$. bicolor). Perlakuan $\mathrm{C}$ memiliki nilai Pertumbuhan Spesifik tertinggi dari

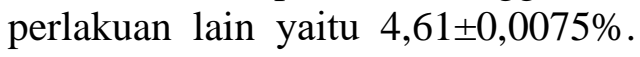
Hasil laju pertumbuhan spesifik dapat dilihat pada Gambar 1.

Seiring dengan peningkatan jumlah proporsi minyak ikan yang di berikan. Ikan membutuhkan energi yang besar dalam memproduksi sel serta menjaga fungsi sel. Ketersediaan total energi yang tepat pada pakan menyebabkan protein dimanfaatkan dengan efisien untuk menyusun jaringan tubuh yang baru sehingga menghasilkan pertumbuhan 
yang tinggi. Hal ini sesuai dengan pernyataan Retno penambahan minyak ikan sebanyak 5\% masih mampu merombak kandungan nutirisi pakan kedalam tubuh sehingga energi dalam pakan dapat digunakan. Dalam penelitian ini pakan yang di pengkaya menggunakan minyak ikan mencukupi kebutuhan pertumbuhan ikan sidat pada semua perlakuan. Pakan yang dikonsumsi oleh ikan mengandung berbagai macam zat diantaranya protein, lemak, karbohidrat, serat kasar, vitamin dan mineral. Salah satu nutrient yang diperlukan oleh ikan adalah lemak (Hariati,1989). Hal ini menunjukkan bahwa pakan yang telah diberikan selama percobaan telah melebihi kebutuhan standar tubuh (maintenance), sehingga kelebihannya dapat dialokasikan untuk membangun tubuh sebagai bentuk pertumbuhan. Kebutuhan energi untuk maintenance harus terpenuhi dahulu sebelum terjadinya pertumbuhan. Halver dan Hardy (2002) menyatakan bahwa kebutuhan energi untuk maintenance harus terpenuhi dahulu sebelum terjadinya pertumbuhan.

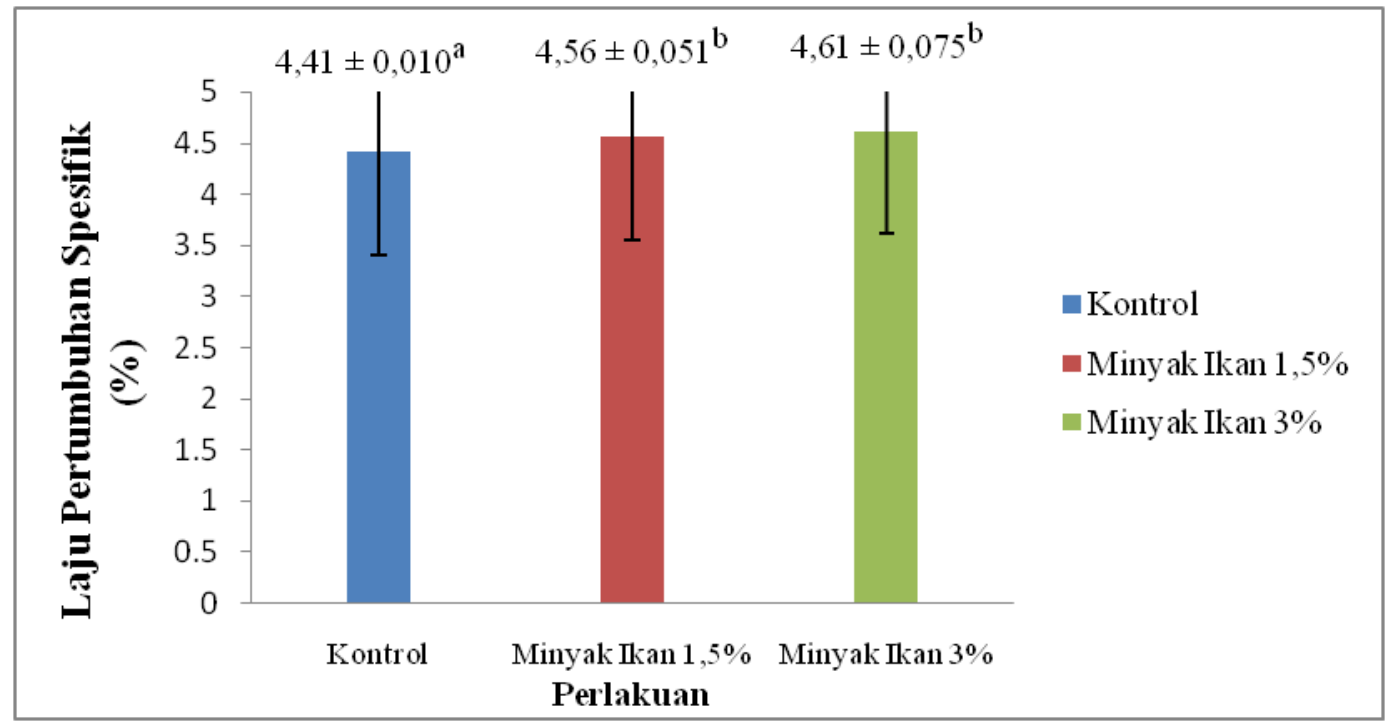

Gambar 1. Laju Pertumbuhan Spesifik (LPS)

Jumlah Konsumsi Pakan (JKP)

Hasil analisis ragam menunjukan bahwa penambahan minyak ikan pada pakan buatan dengan dosis yang berbeda berpengaruh terhadap jumlah konsumsi pakan. Hasil jumlah konsumsi pakan dapat dilihat pada Gambar 2.

Jumlah konsumsi pakan pada penelitian didapat pada perlakuan A (0\% tanpa minyak ikan ) 403,7 g, B (1,5\% minyak ikan) $243,7 \mathrm{~g}$, dan perlakuan C (3\% minyak ikan ) 264,5 g. Pada perlakuan A merupakan perlakuan yang tertinggi dibandingkan $\mathrm{B}$ dan $\mathrm{C}$, hal ini dinyatakan bahwa kelebihan lemak dalam pakan tidak dianjurkan karena dapat menurunkan jumlah konsumsi pakan (Ling et al., 2006). Jumlah konsumsi pakan pula menunjukkan kecenderungan peningkatan dengan bertambahnya kadar protein pakan meskipun tidak terdapat perbedaan 
nyata antar perlakuan B dan C. Pemanfaatan kadar protein dan pertumbuhan ikan dapat dioptimalkan dengan memberikan rasio energi protein yang tepat (Kaushik dan Seiliez, 2010). Penurunan jumlah konsumsi pakan dipengaruhi oleh nafsu makan ikan tersebut. Sesuai dengan pernyataan Perwito (2015) yaitu apabila nafsu makan ikan berkurang maka jumlah pakan yang dikonsumsi akan berkurang sehingga pertumbuhan menjadi rendah..

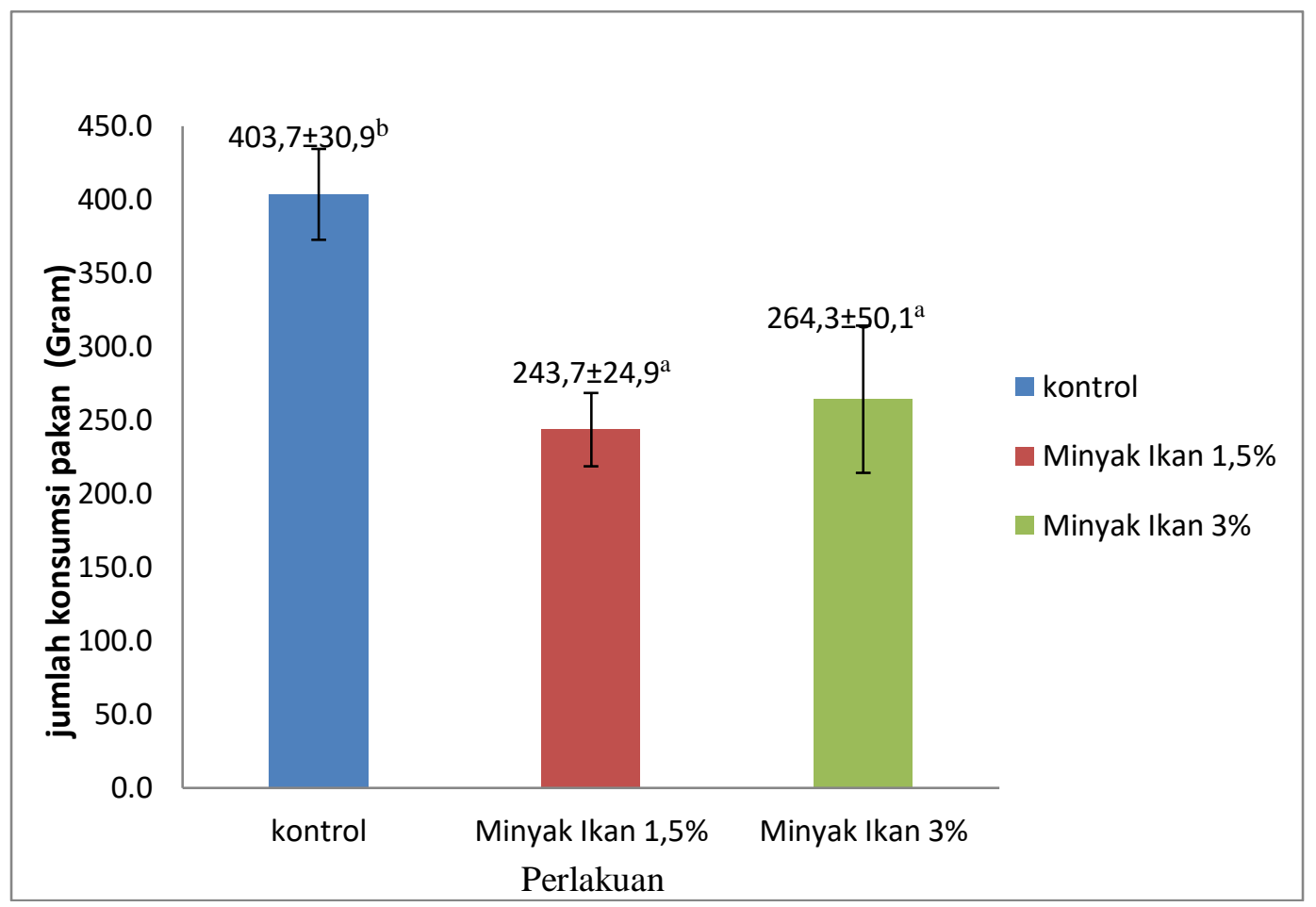

Gambar 2. Jumlah Konsumsi Pakan (JKP)

\section{Efisiensi Pakan (EP)}

Nilai efisiensi pakan dari terendah hingga tertinggi sebagai berikut: pada perlakuan C $(42,7 \%)$, B $(43,3 \%)$ dan tertinggi pada perlakuan A $(64,7 \%)$ Berdasarkan hasil uji statistik pada selang kepercayaan 95\% pakan antara $\mathrm{A}, \mathrm{B}$ dan $\mathrm{C}$ menunjukkan hasil yang tidak berbeda nyata Hasil efisiensi pakan dapat dilihat pada Gambar 3.

Ikan sangat membutuhkan pakan yang berkualitas yang baik dan ketersediaan yang kontinyu untuk tumbuh dan berkembang secara optimal. Kualitas pakan dapat ditententukan dengan kandungan nutrisi dan kandungan energi yang sesuai untuk pertumbuhan ikan. Pakan yang dikonsumsi ikan mengandung berbagai macam nutrisi yang harus tersedia antara lain protein, lemak, karbohidrat, mineral, dan vitamin kebutuhan nutrisi tersebut mendukung kelangsungan hidup dan pertumbuhan. Kebutuhan protein bagi ikan sidat Anguilla bicolor yaitu 50\% (Mahi, 2002).

Hasil perlakuan A menunjukkan hasil tertinggi bila dibandingkan dengan perlakuan lainnya, diduga bahwa ikan uji 
perlakuan A mampu memanfaatkan pakan dengan baik sehingga pemberian pakan lebih efisien. Hasil antara pertumbuhan ikan sidat dengan efisiensi pakan pun berbanding terbalik. Hal ini dikarenakan pada perlakuan A terdapat ikan yang mengalami kematian sehingga nilai efisiensi pakan meningkat sehingga ruang gerak ikan dalam media pemeliharaan menjadi lebih luas sehingga pakan yang diberikan pada ikan sidat dimanfaatkan sebagai energi dari pakan untuk melakukan pergerakan serta memperbaiki jaringan tubuh lebih dahulu dibandingkan untuk melakukan pertumbuhan yang kemudian ikan sidat tidak dapat memanfaatkan lemak secara maksimal

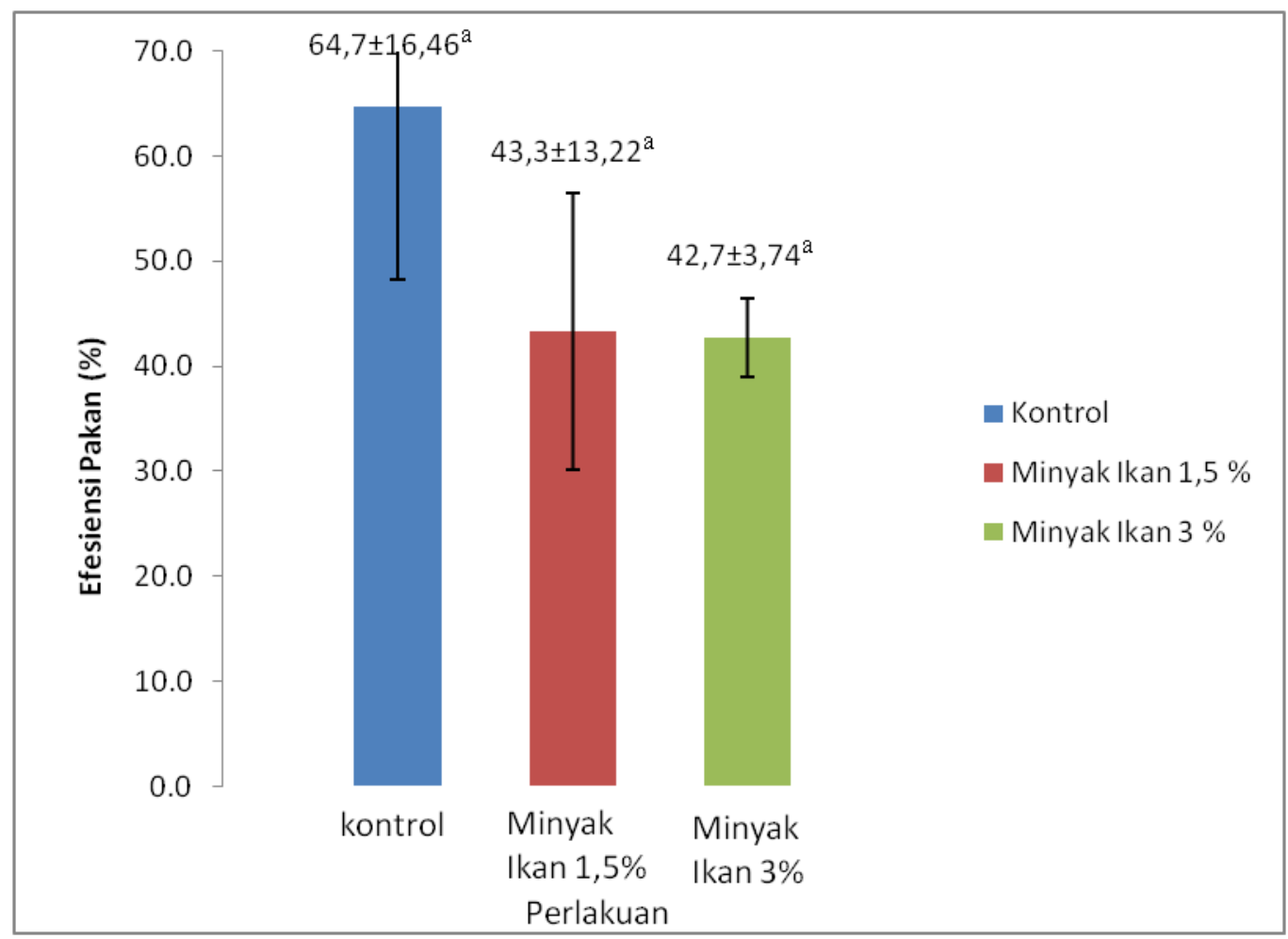

Gambar 3. Efisiensi Pakan (EP)

\section{Retensi Lemak}

Retensi lemak ikan sidat yang terendah sampai tertinggi yaitu didapat pada perlakuan A $(2,04 \%)$, B $(2,15 \%)$ dan yang tertinggi terdapat pada perlakuan C $(2,97 \%)$. Berdasarkan hasil uji statistik pada selang kepercayaan 95\% menunjukkan bahwa antara perlakuan A, B dan C tidak berbeda nyata terhadap retensi lemak dapat dilihat pada Gambar 4.
Nilai retensi lemak yang rendah mengindikasikan bahwa adanya penambahan atraktan menyebabkan peningkatan konsumsi ransum pakan pada ikan sehingga turut meningkatkan jumlah serat kasar dalam pakan yang dikonsumsi ikan. Hal ini sesuai dengan pendapat Fitriliyani (2010) dalam Abidin (2011) bahwa semakin banyak konsumsi serat, semakin tinggi pula proporsi lemak yang terbuang. Hal ini menyebabkan lemak yang diserap 
oleh tubuh semakin sedikit. Menurut penelitian Mukti (2014) membuktikan bahwa ikan sidat membutuhkan asam lemak n-3 dalam

jumlah terbatas dan diduga bahwa penambahan minyak ikan sebesar 5\% telah memenuhi kebutuhan asam lemak ikan sidat.

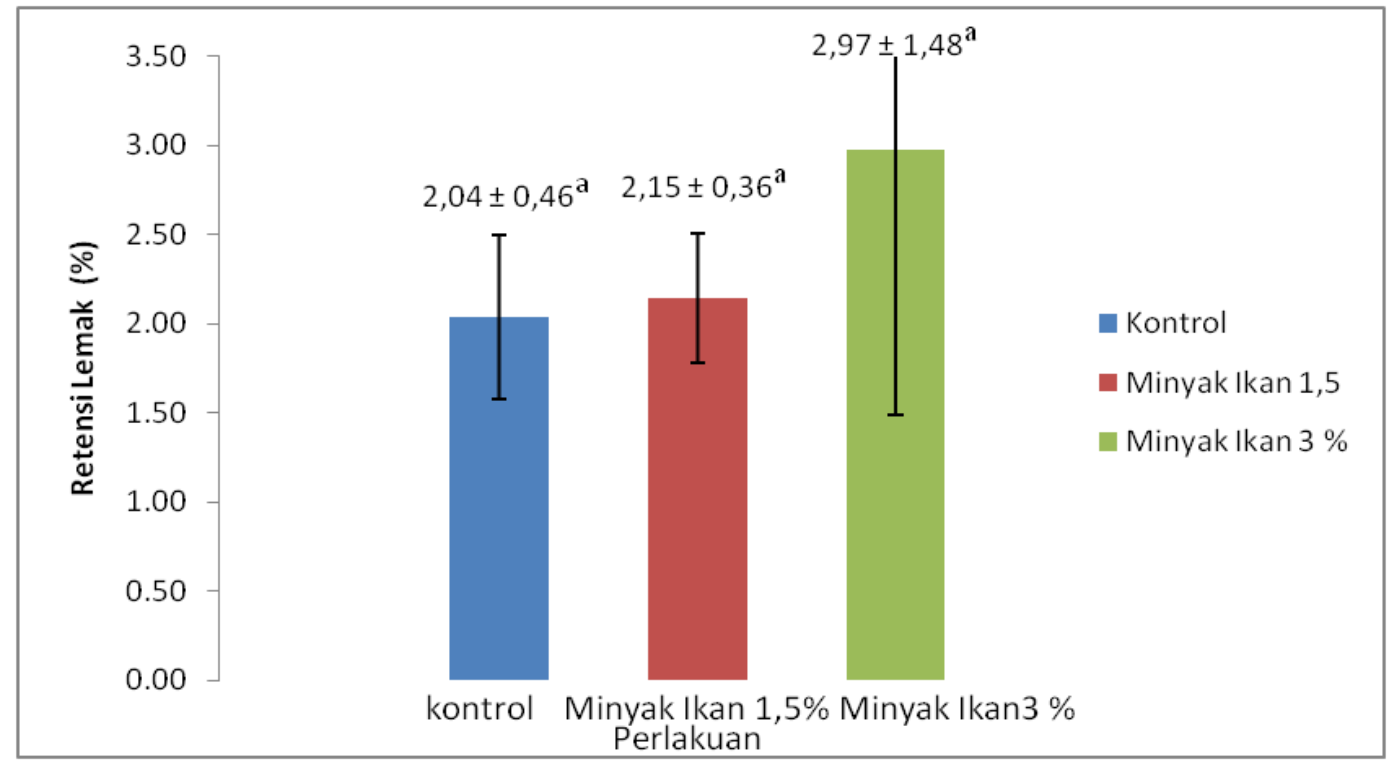

Gambar 4. Retensi Lemak Tubuh Ikan Sidat

Tingkat Kelangsungan Hidup (TKH)

Berdasarkan hasil akhir penelitian selama 60 hari didapatkan nilai dari tertinggi hingga terendah yaitu: pada perlakuan $\mathrm{C}$ merupakan nilai tertinggi $(86,7 \%)$, perlakuan $\mathrm{A}$ $(73,3 \%)$ dan nilai terendah terdapat pada perlakuan B (60\%). Berdasarkan hasil uji statistik pada selang kepercayaan 95\% menunjukkan hasil bahwa perlakuan A tidak berbeda nyata dengan perlakuan $\mathrm{B}$ dan $\mathrm{C}$, perlakuan $B$ tidak berbeda nyata dengan perlakuan A tetapi berbeda nyata dengan $C$, perlakuan $C$ tidak berbed a nyata dengan perlakuan $\mathrm{A}$ tapi berbeda nyata dengan B (Gambar 5). 


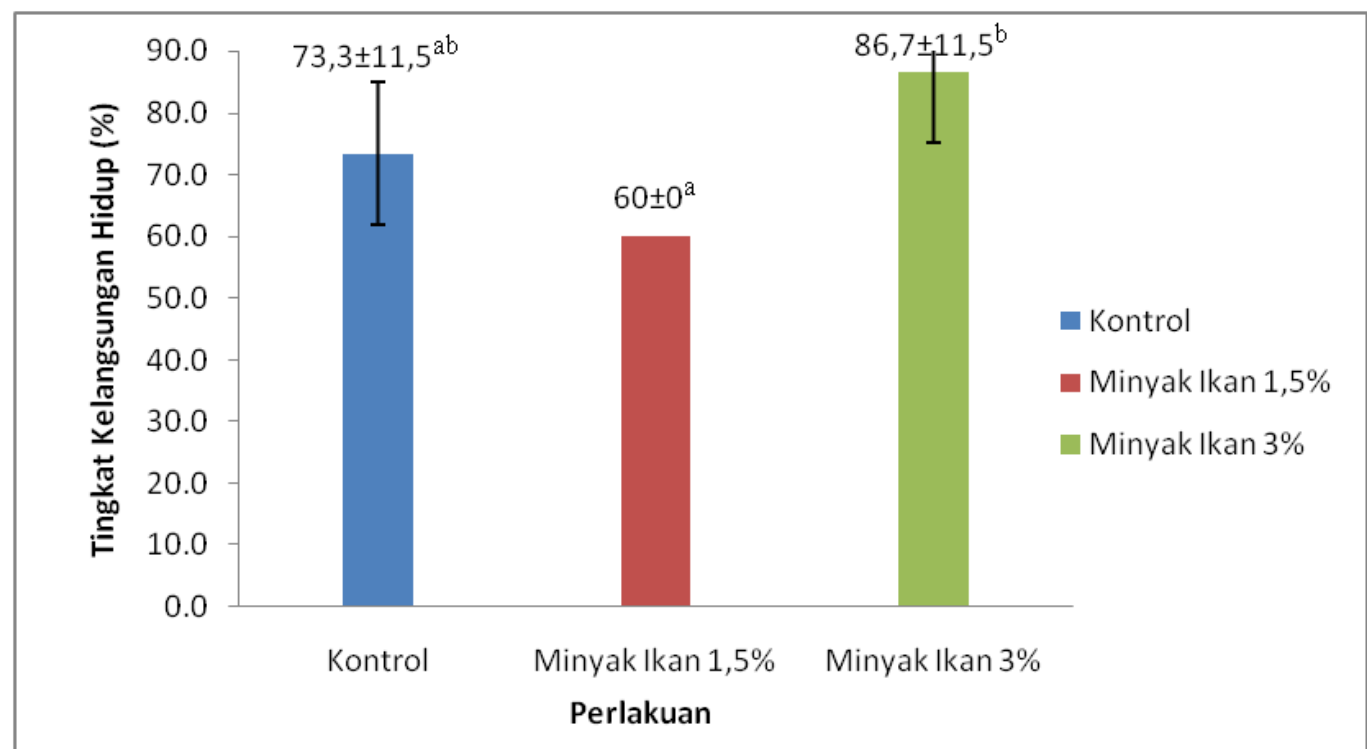

Gambar 5. Tingkat Kelangsungan Hidup

Perlakuan B mengalami kematian yang tinggi dibandingkan dengan kontrol dan penambahan minyak ikan $3 \%$ dengan kepadatan yang tinggi mempengaruhi proses fisiologi dan tingkah laku ikan terhadap ruang gerak. Hal ini dapat menurunkan kondisi kesehatan dan fisiologi ikan, ikan akan sulit memanfaatkan pakan sehingga menyebabkan penurunan tingkat kelangsungan hidup rendah (Handajani dan Hastuti, 2002). Tingkat kelangsungan hidup tidak dipengaruhi secara langsung oleh pakan. Kematian ikan sidat selama penelitian diduga karena stres selama penelitian dan adanya kelebihan pakan yang tidak digunakan sehingga menyebabkan kerusakan hati pada ikan sidat. Tingkat kelangsungan hidup dipengaruhi oleh faktor biotik dan abiotik. Faktor biotik terdiri dari umur dan kemampuan ikan dalam menyesuaikan diri dengan lingkungan tempat hidup. Faktor abiotik antara lain ketersediaan makanan dan kualitas media hidup. Nilai kualitas air pada penelitian ini memliki kisaran optimal dengan penelitian Otwell dan Rickards (1982) bahwa nafsu makan ikan sidat pada suhu $24-28^{\circ} \mathrm{C}$.

\section{Kualitas Air}

Parameter pendukung dalam penelitian ini yaitu kualitas air yang meliputi suhu, $\mathrm{pH}$, dan DO. Dimana parameter tersebut diamati pada awal, tengah dan akhir selama pemeliharan ikan sidat. Hasil pengukuran kualitas air dapat dilihat pada Tabel 1 .

Tabel 1. Hasil pengukuran kualitas air.

\begin{tabular}{ccc}
\hline Parameter & Kisaran & Baku Mutu \\
\hline Suhu $\left({ }^{\circ} \mathrm{C}\right)$ & $25-26$ & $20-29$ (Suryono dan Badjoeri, 2013) \\
$\mathrm{pH}$ & $6-7$ & $6-8$ (Herianti, 2005) \\
DO $(\mathrm{mg} / \mathrm{l})$ & $5-6$ & $5-6($ Bhatnagar dan Devi, 2013) \\
\hline
\end{tabular}


Kualitas air dalam masa pemeliharan ikan sidat selama 60 hari tergolong optimal untuk pertumbuhan ikan sidat. Kualitas air yang baik dalam media pemeliharaan merupakan faktor yang sangat mendukung pertumbuhan ikan sidat. Suhu air selama penelitian dari masing-masing perlakuan berkisaran $25-26^{\circ} \mathrm{C}$. Hal ini sesuai hasil penelitian Suryono dan Badjoeri (2013) yang menyatakan bahwa suhu air yang optimal untuk pertumbuhan ikan sidat adalah $20-29^{\circ} \mathrm{C}$. Suhu sangat berpengaruh pada nafsu makan. Dengan optimumnya suhu dapat meningkatnya konsumsi pakan pada akhirnya akan menentukan laju pertumbuhan.

\section{Uji Proksimat Pakan dan Tubuh Ikan} Sidat

Hasil analisis proksimat kandungan nutrisi pakan yang telah ditambahkan dengan minyak ikan dapat dilihat pada Tabel 2.

Tabel 2. Uji Proksimat Pakan

\begin{tabular}{lccc}
\hline \multirow{2}{*}{ Kandungan } & \multicolumn{3}{c}{ Pakan Perlakuan } \\
\cline { 2 - 4 } & $\mathbf{A}$ & $\mathbf{B}$ & $\mathbf{C}$ \\
\hline Kadar air & 7,68 & 11,47 & 10,33 \\
Protein & 34,40 & 32,45 & 32,80 \\
Lemak & 4,44 & 5,40 & 7,07 \\
Kadar abu & 9,07 & 8,07 & 8,30 \\
Serat kasar & 2,43 & 1,50 & 2,28 \\
Karbohidrat & 41,97 & 41,12 & 39,26 \\
\hline
\end{tabular}

Hasil analisis proksimat kandungan nutrisi daging ikan sidat yang telah ditambahkan minyak ikan dapat dilihat pada Tabel 3.

Tabel 3. Hasil Uji Proksimat Daging

\begin{tabular}{cccccccc}
\hline \multirow{2}{*}{ No } & Kode & Padatan & Abu & Protein & Lemak & Serat Kasar. & Karbohidrat \\
\cline { 2 - 8 } & Sampel & \multicolumn{5}{c}{$(\%$ Berat basah) } \\
\hline 1 & Awal & 71,23 & 1,78 & 16,00 & 3,50 & 2,77 & 4,70 \\
2 & A & 70,42 & 1,09 & 16,90 & 5,95 & 2,50 & 3,12 \\
3 & B & 68,29 & 1,13 & 15,46 & 6,60 & 2,90 & 5,62 \\
4 & C & 67,97 & 1,13 & 15,30 & 7,08 & 2,48 & 6,04 \\
\hline
\end{tabular}

Berdasarkan hasil uji proksimat pakan dan daging ikan sidat yang sudah dilakukan pengkayaan maupun yang tidak perkaya menunjukkan hasil bahwa setiap pakan yang diberi perlakuan memiliki kandungan nutrisi yang berbeda terutama pada lemak. Pakan yang diberi pengkayaan memiliki nilai kandungan lemak meningkat dengan jumlah bahan pengkayaan yang ditambahkan kedalam pakan namun pakan yang tidak diberi bahan pengkayaan memiliki nilai kandungan terendah. Penambahan minyak ikan dalam pakan ikan sidat A. bicolor bicolor dapat dilakukan sampai dengan 5\% (kadar lemak pakan 13\%). Dalam pemberian pakan dapat mengakibatkan terjadinya penurunan atau peningkatan laju pertumbuhan hal ini sesuai dengan pernyataan Hepher (1981), karena ketersediaan pakan hanya cukup untuk memenuhi 
pemeliharaan tubuhnya, namun tidak mencukupi untuk kebutuhan pertumbuhan. Dengan tingginya kandungan lemak akan mengganggu aktivitas enzim-enzim pada membran sel, sehingga sintesis protein dan sel juga rendah yang akhirnya berakibat pada rendahnya laju pertumbuhan (Takeuchi dan Watanabe,1979).

\section{Kesimpulan dan Saran}

Kesimpulan dari penelitian ini adalah sebagai berikut:

1. Penambahan minyak ikan kedalam pakan ikan sidat dapat dilakukan sampai dengan $3 \%$.

2. Penambahan minyak ikan sebanyak meningkatkan laju pertumbuhan ikan sidat sampai dengan $4,61 \%$ dan dapat dimanfaatkan sebagai campuran pakan untuk ikan sidat..

\section{Daftar Pustaka}

Abidin, H. 2011. Penggunaan Distilers Dried Grains With Solubles (DDGS) dan Hominy Feed pada Pakan Ikan Kerapu Bebek Cromileptes altivelis. Skripsi. Fakultas Perikanan dan Ilmu Kelautan, Institut Pertanian Bogor, Bogor. $31 \mathrm{Hal}$.

Affandi, R., T. Budiardi, R.W. Irawan, dan A.T. Azbas. 2013. Pemeliharaan ikan sidat dengan sistem air bersirkulasi. Jurnal Ilmu Pertanian Indonesia, 18(1): 55 60.

Bhatnagar A., dan P. Devi. 2013. Water quality guidelines for the management of pond fish culture. International Journal of Environtmental Sciences, 3: 1.980 -2.009 .
Djajasewaka, H. 1990. Makanan Ikan (Pakan Ikan). Cetakan I. Penerbit Yasaguna, Jakarta. 45 hal.

Gerking dan D. Shelby. 1972. Revised food consumption estimate of bluegill sunfish poplation in wyland lake indiana. USA. Journal of fish biology, 4: $301-308$.

Hangesti, R.A.W., C.M. Kusharto, Budywiryawan, E.S. Wiyono, dan S.H. Suseno. 2014. Nutritive value and fatty acids profile of fresh Indonesian eel (Anguilla bicolor) and Kabayaki. Jurnal Sains Kesihatan Malaysia, 12(1): 41 46.

Handajani, H., dan S.D. Hastuti. 2002. Budidaya Perairan. Bayu Media, Malang. $199 \mathrm{hlm}$.

Hepher, B. 1981. Nutrition on pond fishes. Cambridge University Press, Great Britain

Herianti, I. 2005. Rekayasa Lingkungan Untuk Memacu Perkembangan Ovarium Ikan Sidat Anguilla Bicolor. Oseanologi dan Limnologi, 37: 25 $-41$.

Kaushik S.J., dan I. Seiliez. 2010. Protein and amino acid nutrition and metabolism in fish: Current knowledge and future needs. Aquaculture Research, 41: 322 332.

Leaver, M.J., J.N. Bautista, B.T. Bjornsson, E. Jonnson, G. Krey, D.R. Tocher, dan B.E. Torstensen. 2008. Toward fish lipid nutrigenomics: Current state and prospect for fin-fish aquaculture. Rev. Fish. Sci., 16: 73 - 94

Ling, S., R. Hashim, S. Kolkovski, dan A.S.C. Chong. 2006. Effects of varying dietary lipid and protein levels on growth and reproductive 
performance of female Swordtail fish (Xiphorus helleri, Poeciliidae). Aquaculture Research, 37: 1.267 - 1.275.

Mahi, I.I. 2000. Pengaruh Kadar Protein Dan Imbangan Energi Protein Pakan Berbeda Terhadap Retensi Protein Dan Pertumbuhan Benih Ikan Sidat Anguilla Bicolor. Tesis. Institut Pertanian Bogor, Bogor.

Mukti, R.C, N.B.P. Utomo, dan R. Affandi. 2014. Penambahan Minyak Ikan Pada Pakan Terhadap Kinerja Pertumbuhan Dan Komposisi Asam Lemak Ikan Sidat Anguilla bicolor bicolor. Jurnal Akuakutur Indonesia, 13(1): $54-60$.

Otwell, W.S., dan W.L. Rickards. 1982. Cultured and Wild Americans Eel (Anguilla rostrata) Fat Content and Fatty Acid Composition. Aquaculture, 26: 67 -76 .

Perwito, B., S. Hastuti, dan T. Yuniarti. 2015. Pengaruh Lama Waktu Perendaman Recombinant Growth Hormone (rGH) terhadap Pertumbuhan dan Kelulushidupan Larva Nil Salin (Oreochromis niloticus). Journal of Aquaculture Management and Technology, 4(4): 117 - 126.

Purwanto, J. 2007. Pemeliharaan Benih Ikan Sidat (Anguilla bicolor) dengan Padat Tebar yang Berbeda. Bul. Tek Lit. Akuakultur, 6(2): $85-89$.

Sasongko, J. Agus, S. Purwanto, U. Mu'minah, dan Arie. 2007. Sidat. Penebar Swadaya: Jakarta. 115 hal.

Suryono, T., dan M. Badjoeri. 2013. Kualitas air pada uji pembesaran larva ikan sidat Anguilla spp. dengan sistem pemeliharaan yang berbeda. Limnotek, 20(2): 169 177.

Takeuchi, T., dan T. Watanabe. 1979. Effect of excess amounts of essential fatty acids on growth of rainbow trout. Bulletin of the Japanese Society of Scientific Fisheries, 45(12): 1.517 - 1.519.

Takeuchi, T. 1988. Laboratory workchemical evaluation of dietery nutrients. In: Fish Nutrition and Mariculture (ed. By T. Watanabe), pp. 179 - 233. Kanagawa International Fisheries Training Center, Japan International Cooperation Agency, Kagawa.

Watanabe, T. 1988. Fish Nutrition and Mariculture. Kanagawa Fisheries Training Center, Japan International Cooperation Agency, Tokyo. 233 hal.

Zonneveld, N., E.A. Husiman, dan J.H. Boon. 1991. Prinsip-Prinsip Budidaya Ikan. PT. Gramedia Pustaka Utama, Jakarta. 
